\title{
Improvement courses about violence prevention: the impact on health sector professionals
}

\author{
CURSOS DE CAPACITAÇÃO EM PREVENÇÃO DA VIOLÊNCIA: O IMPACTO SOBRE OS \\ PROFISSIONAIS DO SETOR DA SAÚDE
}

\author{
CURSOS DE FORMACIÓN EN PREVENCIÓN DE LA VIOLENCIA: EL IMPACTO EN \\ PROFESIONALES DEL CAMPO DE LA SALUD
}

\section{Stephanie Pereira1, Lucila Amaral Carneiro Vianna²}

\begin{abstract}
Uncontrolled intervention study that compared the effectiveness of two elective courses on Prevention and Assistance to violence victims for students and professionals of the Health Sector. The participants answered multiple-choice questions on the topic before and after the course. Statistical analyzes were performed by comparison of two proportions on STATA/IC. Regarding the overall index of correct answers, before and after, it was 54.8 and $58.4 \%$ in the $10 \mathrm{~h}$ Course and the 69.6 and $79.2 \%$ in the $30 h$ Course. The most effective course was the $30 \mathrm{~h}$ Course, with strategies of case discussions and visits to assistance services to violence victims. There is a great necessity to include the discipline in the curriculum of healthcare courses permanently.
\end{abstract}

\section{DESCRIPTORS}

Violence

Training

Health personnel

Students, health occupations

Health promotion

\section{RESUMO}

Estudo de intervenção não controlado, com o objetivo comparar a efetividade de dois cursos eletivos sobre Prevenção e Tratamento às Pessoas Vulneráveis à Violência para estudantes e profissionais da área da saúde. Os participantes responderam questões de múltipla escolha sobre o tema antes e depois da disciplina. As análises estatísticas foram realizadas por comparação de duas proporções no Programa STATA/IC. Quanto ao índice geral de acertos, antes foi de $54,8 \%$ e $58,4 \%$ nos cursos de $10 \mathrm{~h}$ e $30 \mathrm{~h}$ e depois $69,6 \%$ e $79,2 \%$ respectivamente. Conclui-se que a maior efetividade foi do Curso 30h, com estratégias de discussão de casos e visitas aos serviços de atendimento às vítimas. Constatou-se a necessidade de inclusão efetiva da disciplina nos cursos da área da saúde.

DESCRITORES
Violência
Capacitação
Pessoal de saúde
Estudantes de ciências da saúde
Promoção da saúde

\section{RESUMEN}

Estudio de intervención no controlado cuyo objetivo fue comparar la efectividad de dos cursos electivos sobre Prevención y Tratamiento de la Violencia de Personas Vulnerables para estudiantes y profesionales del área de la salud. Los participantes respondieron a preguntas de opción múltiple sobre el tema antes y después del curso. Los análisis estadísticos se realizaron por comparación de dos proporciones en el programa STATA/IC. EI índice general de éxito antes y después en los cursos de 10 horas fue de $54,8 \%$ y de $58,4 \%$ respectivamente y en los cursos de 30 horas fue de $69,6 \%$ y $79,2 \%$. Se concluye que el curso más efectivo fue el de 30 horas, con estrategias de discusión de casos y visitas a los servicios de atención a las víctimas. Se constató la necesidad de incluir el curso en los programas del área de la Salud.

\author{
DESCRIPTORES \\ Violencia \\ Capacitación \\ Personal de salud \\ Estudiantes del área de la salud \\ Promoción da la salud
}

\footnotetext{
${ }_{1}^{1}$ Nurse graduated at the Escola Paulista de Enfermagem, Universidade Federal de São Paulo, São Paulo, SP, Brazil. stephaniepeee@hotmail.com ${ }^{2}$ Full Professor of the Escola Paulista de Enfermagem, Universidade Federal de São Paulo, São Paulo, SP, Brazil. 


\section{INTRODUCTION}

Currently, violence is considered a serious public health problem in view of the various determinants that surround it. It is understood that the suffering caused by situations of violence and vulnerability makes the patients lose their social identity. A study shows that the lack of staff training and problem-solving found in health services are also considered forms of violence ${ }^{(1)}$. Thus, a non-humanized service reaffirms this loss of identity and can lead to lack of recognition of citizenship. Noteworthy is the need to banish from the health services the reproduction of violence already experienced by users.

The issue of violence is extremely important in Brazil and worldwide. Hence, the need to create effective and guiding public policies for health services. In addition, curriculum guidelines which provide the effective inclusion of this topic in the curriculum grid of the health courses ${ }^{(2-3)}$.

The National Policy for Reduction of Morbidity and Mortality from Accidents and Violence (Política Nacional de Redução da Morbimortalidade por Acidentes e Violência) was approved as an addendum to the Ordinance no. 737/ GM in May, 2001 ${ }^{(4)}$. This policy establishes responsibilities and institutional guidelines that include actions for the promotion of health and prevention of violence. It proposes the articulation of different social segments, each performing a specific role, with strategies for a better adaptation of actions related to assistance, recovery and rehabilitation of victims. Furthermore, there is still much to do in relation to human resources, both in numerical issues, as in training. It is the responsibility of universities to train professionals able to meet situations of emergency and victims of violence as well as developing preventive measures.

In 2004, aiming at integrating the issue of violence and the training of professionals to act in the field, was approved the Ordinance no. $936^{(5)}$. It addresses the structuring of the National Network for the Prevention of Violence and Promotion of Health and the implementation of Centers for the Prevention of Violence in the states and municipalities. The Article no. 2 defines departments and agencies that will constitute these centers and among them are the academic institutions.

In the Universidade Federal de São Paulo (UNIFESP), the Associate Center for Violence Prevention (Núcleo Associado de Prevenção à Violência - NUPREVI), linked to the School of Extension, aims to empower and sensitize health professionals to identify and appropriately assist the victims of domestic and sexual violence, in addition to establishing partnerships with municipal and state health services. The professionals of the NUPREVI created an elective subject to meet the deficit of knowledge on the topic in undergraduate courses of the UNIFESP.

This research aims to compare the effectiveness of two elective courses on prevention and assistance to persons in situations of violence. It also aims to investigate the sociodemographic profile of the participants of these two courses, their perception on violence against people and analyze their training to identify and assist victims of violence.

\section{METHOD}

This is an uncontrolled, intervention study involving the manipulation of the exposure factor (intervention), i.e., it intentionally causes a modification in some aspect of the individual or community. An uncontrolled intervention study is also called a before and after study, in which the community is assessed before and after the intervention ${ }^{(6)}$. In this study, the exposure factor is the knowledge offered in the elective course.

The research was carried out during two elective courses on prevention and care for people vulnerable to violence at the Universidade Federal de São Paulo, in the periods between August and October/2011 (30h) and May/2012 (10h).

Nursing and medicine students of the second and third years attended the first course with a 30-hour load (of which 22 were theoretical). The strategy of case discussion was used and in the remaining eight hours the UNIFESP services, and services of other institutions that assist victims of violence were visited. The second course, with a 10-hour load, had medicine students in their first and second years; nursing students of the first, second and third years, and psychology students from the first and third years. Social workers, psychologists and a biologist also enrolled in this course. The second course was theoretical only (lectures). A total of 50 individuals participated in the study, being 25 in the first course and 25 in the second.

Considering the proposed objectives, the socio-demographic variables of the study were gender, age, religious belief and academic training. And also regarding the knowledge about violence against women, children, elderly and homosexuals, the epidemiology of violence, the psychological violence and the post trauma -violence.

Questionnaires divided into two parts were used for data collection. The first had sociodemographic variables and the second had eleven multiple-choice questions to assess the knowledge offered/acquired in the course. These questionnaires were completed before the beginning of the course and in the last day of the course. The multiple-choice questions contained five options to be chosen and questioned different aspects of violence (Tables 1, 2 and 3).

Incomplete questionnaires were excluded. The second questionnaire was not given to the students who had not answered the first one (either because they were not present on the first day of the course or because they arrived after the arranged time to answer the questionnaire).

In order to simplify the understanding, the questionnaire completed before the course was named Before and the one answered after completion of the course was called $A f$ ter. The same was done with the courses. The 30-hour load 
course was named $30 \mathrm{~h}$ course and the 10hour-load course was named $10 \mathrm{~h}$ course.

Statistical analysis were performed by comparing two proportions in the STATA/IC software, version 11.2, reaching a confidence level of $95 \%{ }^{(7)}$.

This study is part of another multiprofessional study: Prevention and assistance to victims of sexual and domestic violence, developed by the NUPREVI (Associate Center for Violence Prevention), which was approved by the Committee of Ethics and Research of the Universidade Federal de São Paulo under no. 1320/09.

The respondents (not identified for reasons of confidentiality) were duly informed about the details of the study and signed a consent form.

\section{RESULTS}

Below are shown the socio-demographic profiles of the participants of the two elective courses on prevention and assistance to victims of violence. In both the courses (with a 30-hour load and 10-hour load) most of the participants were females (80\%). The predominant age group was between 17 and 25 years, which represented $76 \%$ of the enrolled in the $10 \mathrm{~h}$ course and $100 \%$ of the enrolled in the $30 \mathrm{~h}$ course. The percentage of religious beliefs varied in both courses; in the $30 \mathrm{~h}$ course, Catholicism predominated $(48 \%)$ and in the $10 \mathrm{~h}$ course there was similar distribution among Catholicism, Evangelical, Spiritism and other religions. As for academic training, in both courses the undergraduate students of medicine predominated, followed by nursing students.

Table 1 - Statistical analysis of the frequency of correct answers on the issues of the 10-hour load course regarding the Before and After - São Paulo, SP, 2012

\begin{tabular}{|c|c|c|c|}
\hline Questions & $\begin{array}{c}\text { Correct } \\
\text { answers } \\
\text { Before }\end{array}$ & $\begin{array}{c}\text { Correct } \\
\text { answers } \\
\text { After }\end{array}$ & $p$ \\
\hline Q1 - Asks whether participants feel prepared to identify and assist victims of violence & $8 \%$ & $76 \%$ & 0.0000 \\
\hline Q2 - Discusses the magnitude of deaths from external causes in Brazil and in São Paulo & $44 \%$ & $24 \%$ & 0.1355 \\
\hline Q3 - Questions the predictor factors of violence & $60 \%$ & $56 \%$ & 0.7745 \\
\hline Q4 - Addresses the immediate care to victims of sexual violence & $52 \%$ & $64 \%$ & 0.3900 \\
\hline Q5 - Asks about the necessary documents to have a legal abortion & $12 \%$ & $72 \%$ & 0.0000 \\
\hline Q6 - Questions risks after sexual abuse & $24 \%$ & $72 \%$ & 0.0007 \\
\hline Q7 - Questions the focus of the approach to children victims of domestic violence & $72 \%$ & $72 \%$ & 0.9999 \\
\hline Q8 - Addresses physical indicators of violence against the elderly & $84 \%$ & $96 \%$ & 0.1573 \\
\hline $\begin{array}{l}\text { Q9 - Addresses the behavior in adulthood of male homosexuals who were victims of sexual } \\
\text { violence in the past }\end{array}$ & $52 \%$ & $84 \%$ & 0.0153 \\
\hline Q10 - Questions characteristics of psychological violence & $80 \%$ & $92 \%$ & 0.2214 \\
\hline Q11 - Addresses the violence in the context of mental health & $68 \%$ & $64 \%$ & 0.7653 \\
\hline Total & $54.80 \%$ & 69.6 & 0.2868 \\
\hline
\end{tabular}

Source: STATA/IC software, version 11.2

Table 2 - Statistical analysis of the frequency of correct answers on the issues of the 30h workload course regarding the Before and After - São Paulo, SP, 2012

\begin{tabular}{|c|c|c|c|}
\hline Questions & $\begin{array}{c}\text { Correct } \\
\text { answers } \\
\text { Before }\end{array}$ & $\begin{array}{c}\text { Correct } \\
\text { answers } \\
\text { After }\end{array}$ & $p$ \\
\hline Q1 - Asks whether participants feel prepared to identify and assist victims of violence & $8 \%$ & $68 \%$ & 0.0000 \\
\hline Q2 - Discusses the magnitude of deaths from external causes in Brazil and in São Paulo & $16 \%$ & $36 \%$ & 0.1069 \\
\hline Q3 - Questions the predictor factors of violence & $84 \%$ & $60 \%$ & 0.0588 \\
\hline Q4 - Addresses the immediate care to victims of sexual violence & $40 \%$ & $100 \%$ & 0.0000 \\
\hline Q5 - Asks about the necessary documents to have a legal abortion & $0 \%$ & $76 \%$ & 0.0000 \\
\hline Q6 - Questions risks after sexual abuse & $32 \%$ & $64 \%$ & 0.0235 \\
\hline Q7 - Questions the focus of the approach to children victims of domestic violence & $72 \%$ & $80 \%$ & 0.5078 \\
\hline Q8 - Addresses physical indicators of violence against the elderly & $84 \%$ & $100 \%$ & 0.0371 \\
\hline $\begin{array}{l}\text { Q9 - Addresses the behavior in adulthood of male homosexuals who were victims of sexual } \\
\text { violence in the past }\end{array}$ & $80 \%$ & $84 \%$ & 0.7128 \\
\hline Q10 - Questions characteristics of psychological violence & $96 \%$ & $100 \%$ & 0.3124 \\
\hline Q11 - Addresses the violence in the context of mental health & $80 \%$ & $92 \%$ & 0.2214 \\
\hline Total & $58.40 \%$ & $79.20 \%$ & 0.1100 \\
\hline
\end{tabular}

Source: STATA/IC software, version 11.2

Improvement courses about violence prevention: the impact on health sector professionals Pereira S, Vianna LAC 
Regarding the perception of participants to identify and assist people in a situation of violence, it was noted that in the Before of the two courses $8 \%$ (2) of participants reported that they felt prepared to identify and assist victims of violence $(p=0.0000)$. Even with a lower course load, the After of the $10 \mathrm{~h}$ course showed that 19 (76\%) participants believed they were able to identify and assist victims of violence, compared with $17(68 \%)$ of the $30 h$ course $(p=0.0000)$. However, there is a difference between this perception and the hit rate of the participants of the two courses: after the end of the course, it was found that the $30 \mathrm{~h}$ course had a greater success rate $(79.2 \%)$ than the $10 \mathrm{~h}$ course (69.6\%), even though this difference was not statistically significant.

In question four there was no statistical significance in the $10 \mathrm{~h}$ course. However, in the $30 \mathrm{~h}$ course the Before had $40 \%$ of correct answers and the After had $100 \%$ $(p=0.0000)$ regarding the immediate care to victims of sexual violence. In this case the inappropriate conduct was the referral of patients to the police in order to file a police report and carry out a corpus delicti exam and only subsequently have medical attention.
Analyzing the question five - about the necessary documents to have a legal abortion in pregnant women victims of sexual violence - in the $30 \mathrm{~h}$ course, none of the participants of the Before versus 10 (76\%) of the After affirmed that the requirements for carrying out a legal abortion would be the patient's request and the complete medical record with the term of consent $(p=0.0000)$. In the $10 \mathrm{~h}$ course three participants (12\%) in the Before and $18(72 \%)$ in the After shared the same opinion ( $p=0.0000)$.

The question number six, regarding the risks of getting pregnant, contracting diseases and the sequelae of sexual abuse for rape victims, has as correct answer that unwanted pregnancy does not happen in more than $50 \%$ of the times. It was found that in the $30 \mathrm{~h}$ course and in the $10 \mathrm{~h}$ course, respectively, eight (32\%) and six (24\%) participants in the Before versus $16(64 \%)$ and $18(72 \%)$ in the After gave the correct answer, with a statistically significant difference in the 10h course only ( $p=0.0007)$.

In both courses, the participants showed no statistically significant differences in the total of their answers in the Before, considering that in the $10 \mathrm{~h}$ course $54.8 \%$ gave correct answers, and in the $30 \mathrm{~h}$ course $58.4 \%$ gave correct answers.

Table 3 - Statistical analysis of the frequency of correct answers to the questions answered in the After of the 10-hour and 30-hour load courses - São Paulo, 2012

\begin{tabular}{|c|c|c|c|}
\hline Questions & $\begin{array}{c}\text { Correct } \\
\text { answers } \\
10 \mathrm{~h} \text { course } \\
\end{array}$ & $\begin{array}{c}\text { Correct } \\
\text { answers } \\
\text { 30h course }\end{array}$ & $p$ \\
\hline Q1 - Asks whether participants feel prepared to identify and assist victims of violence & $76 \%$ & $68 \%$ & 0.5287 \\
\hline Q2 - Discusses the magnitude of deaths from external causes in Brazil and in São Paulo & $24 \%$ & $36 \%$ & 0.3545 \\
\hline Q3 - Questions the predictor factors of violence & $56 \%$ & $60 \%$ & 0.7745 \\
\hline Q4 - Addresses the immediate care to victims of sexual violence & $64 \%$ & $100 \%$ & 0.0009 \\
\hline Q5 - Asks about the necessary documents to have a legal abortion & $72 \%$ & $76 \%$ & 0.7471 \\
\hline Q6 - Questions risks after sexual abuse & $72 \%$ & $64 \%$ & 0.5443 \\
\hline Q7 - Questions the focus of the approach to children victims of domestic violence & $72 \%$ & $80 \%$ & 0.5078 \\
\hline Q8 - Addresses physical indicators of violence against the elderly & $96 \%$ & $100 \%$ & 0.3124 \\
\hline $\begin{array}{l}\text { Q9 - Addresses the behavior in adulthood of male homosexuals who were victims of sexual } \\
\text { violence in the past }\end{array}$ & $84 \%$ & $84 \%$ & 0.9999 \\
\hline Q10 - Questions characteristics of psychological violence & $92 \%$ & $100 \%$ & 0.1489 \\
\hline Q11 - Addresses the violence in the context of mental health & $64 \%$ & $92 \%$ & 0.0169 \\
\hline Total & 69.6 & $79.20 \%$ & 0.4469 \\
\hline
\end{tabular}

Source: STATA/IC software, version 11.2

A statistically significant difference $(p=0.0009)$ was found in the question about which should be the first referral of victims of sexual violence in the After questionnaire. The $30 \mathrm{~h}$ course had $100 \%$ of correct answers and the $10 \mathrm{~h}$ course had $64 \%$.

\section{DISCUSSION}

The evaluation of courses is an important strategy to check the learning of participants and justify its need. This research allowed a comparison between the perceptions of students and the effectiveness of two elective training courses on violence prevention with different hour loads. It was observed that the sociodemographic profiles of the participants were very similar: mostly female, Catholic, aged between 17 and 25 years, and undergraduate students of medicine and nursing.

The unpreparedness of current and future health professionals in identifying and assisting victims of violence calls the attention when analyzing the background of the participants through the completed questionnaires. Such fact can be associated to the current curriculum of higher education in which the issue of violence often goes unnoticed by undergraduates. 
The lack of approach of this subject throughout professional training ends up generating insecurity when identifying and making decisions on assistance to victims of violence, as demonstrated by this study. The difficulty lies in the fact that the current academic formation is strictly biomedical, ignoring biopsychosocial factors and the curricula of colleges still do not address violence in a multidisciplinary way ${ }^{(8)}$.

Sharing the same view, a study carried out in a basic health unit showed that most of the professionals had not been presented to the subject during graduation or it had been addressed simply in an expository way because academic training prioritized technical interventions or those of curative character, in which the theme of violence was left aside ${ }^{(9)}$.

In this study it was found that there was a high rate of errors in the questionnaire answered before the course: $45.2 \%$ in the $10 \mathrm{~h}$ course and $41,6 \%$ in the $30 \mathrm{~h}$ course, considering that most of the questions addressed the social aspects of violence, as well as the attitudes that should be taken in face of the victims. This leads to the conclusion that universities are forming professionals little sensitized to the issue, who prioritize the legal aspects over the assistance aspects, which was noticed in this study. The majority of participants - $60 \%$ of the $10 \mathrm{~h}$ course and $48 \%$ of the $30 \mathrm{~h}$ course in the category Before - wrongly believed that the first assistance to sexual violence victims should be their referral to a police station to file a police report and subsequently have medical attention. There was significant improvement in this aspect, as in the $30 \mathrm{~h}$ course in the category After ( $p=0.0009)$ all the students gave the correct answer for this question.

User embracement is the responsibility of health professionals when receiving the victims of violence, in order to prevent and minimize the trauma sequelae, thus contributing in the process of breaking the cycle of violence. In contrast, the lack of staff training can contribute to the recurrence and worsening of $\operatorname{cases}^{(8,10)}$.

It is important to highlight that user embracement cannot be mistaken for reception, kindness, favor or even immediate care ${ }^{(11)}$. It is in the continuous interaction between users and health services that the user embracement together with its listening skills should be present at every opportunity. Camargo Jr. et al ${ }^{(12)}$ believe in user embracement in three dimensions: as posture, technique and as a principle of service reorientation. As posture, user embracement assumes that the professionals and the healthcare team will have the attitude of receiving, listening and treating users and their demands in a humanized way. Thus a relationship of mutual interest, trust and support is established among professionals and users. As a technique, user embracement instrumentalizes the generation of procedures and organized actions. As a service organization, user embracement represents an institutional project that should guide all the work done by the group of agents and the management policy of the workers and the staff. According to some scholars, user embracement is the humanization of relations between workers and health services with its users ${ }^{(13)}$. It is understood as putting oneself in the place of others, in this case, the victims of violence.

Although the statistical analysis did not present significance in relation to the overall hit rate between the Before and After, the participants showed more security to act on prevention and assistance to victims of violence after watching all the lessons of the course (from $8 \%$ in both courses to $76 \%$ in the $10 \mathrm{~h}$ course and $68 \%$ in the $30 h$ course).

The insecurity experienced by the professionals faced with victims of violence resulted from limited scenarios in the internship, which made it difficult to approximate theory and practice. Moreover, the lack of academic support made them feel unprepared to assist, ending up basing their conduct on experience of life. Undergraduate students claimed that universities had no space to discuss violence from political and philosophical points of view, characterizing the dichotomy between theory and practice ${ }^{(10)}$.

Regarding the questioning about having a legal abortion in pregnant women victims of sexual violen$\mathrm{ce}$, it was found that there was significant improvement in the hit rate of both courses. Before attending the course, only $12 \%$ of the students of the $10 \mathrm{~h}$ course and none of the students of the $30 \mathrm{~h}$ course had adequate knowledge. However, after the course, $72 \%$ of the participants in the $10 \mathrm{~h}$ course and $76 \%$ of the $30 \mathrm{~h}$ course answered correctly to the question that for the termination of pregnancy would be required the request of the patient, the complete medical record and the term of consent. The lack of knowledge of the women's rights can lead to delays in the procedure and serious emotional harm to the victim.

Since 1990, the Penal code of Brazil does not criminalize abortion in case of sexual violence and the government started to offer the service of legal abortion in accredited hospitals. Despite the current law, the population and the health professionals still reject the abortion based on religious and moral precepts. In 2004, the Technical Department of the Woman's Health of the Ministry of Health proposed an update to the Technical Standard in which it would be necessary to show a police report to have an abortion. This was not approved since women are not obliged to file a police report. Nowadays, only the consent of the woman is necessary ${ }^{(14)}$.

Comparing the two elective courses, we observed that initially the participants shared similar levels of knowledge, as evidenced by the level of correct answers in the Before, $54.8 \%$ and $58.4 \%$ for the $10 \mathrm{~h}$
Improvement courses about violence prevention: the impact on health sector professionals Pereira S, Vianna LAC 
course and $30 \mathrm{~h}$ course, respectively. After the course, it was noticed an increase in this index, which differed by $9.6 \%$ more in the $30 h$ course. Furthermore, comparing the Before and After of both courses participants, statistically significant differences were noted in only a few subjects: predisposing factors to violence; sexual violence; violence against homosexuals and their interface with mental health. These differences relate to the fact that the $30 \mathrm{~h}$ course had more time to discuss the cases, in addition to visits to the assistance centers, covering services specialized in psychiatry (PROVE) and in sexual violence (Casa Domingos Delascio, Casa Beth Lobo and Casa Eliane de Grammont).

\section{CONCLUSION}

When comparing two elective courses on prevention and assistance to victims of violence for students and health professionals, this study shows the greater effectiveness of the longer course due to teaching strategies grounded in discussion of cases and contact with assistance services to victims.

Regarding the perception of violence against people, the professionals of the health field showed statistically positive results in terms of knowledge after the courses, feeling better prepared to identify and assist victims of violence.

Aiming at a more humanized care, it is noticeable the necessity to include the subject Prevention and assistance to victims of violence in the curricula of courses of the health field, forming qualified professionals to notice the violence and above all acting towards user embracement and reception of victims.

A possible limitation of this study may be that the sample is restricted and there were losses because not all participants answered the questionnaire on the two provided occasions.

\section{REFERENCES}

1. Villela WV, Vianna LAC, Lima LFP, Sala DCP, Vieira TF, Vieira ML, et al. Ambiguidades e contradições no atendimento de mulheres que sofrem violência. Saúde Soc. 2011;20(1):113-23.

2. Brasil. Ministério da Educação; Conselho Nacional de Educação, Câmara de Educação Superior. Parecer CNE/CES n. 1133, de 7 agosto de 2001. Institui as diretrizes curriculares nacionais dos Cursos de Graduação em Enfermagem, Medicina e Nutrição [Internet]. Brasília; 2001[citado 2013 jul. 15]. Disponível em: http://www.mec. gov.br/Sesu/diretriz. shtm\#legislação

3. Berger SMD. Violência entre parceiros íntimos: desafios no ensino e atenção em saúde. Rev Bras Educ Med. 2011;35(4):526-34.

4. Brasil. Ministério da Saúde. Portaria no 737/GM, de 16 de maio de 2001. Política Nacional de Redução da Morbimortalidade por Acidentes e Violências. Diário Oficial da União, Brasília, 18 maio 2001. Seção 1E.

5. Brasil. Ministério da Saúde. Portaria no 936/GM, de 18 de maio de 2004. Dispõe sobre a estruturação da Rede Nacional de Prevenção da Violência e Promoção da Saúde e a Implantação e Implementação de Núcleos de Prevenção à Violência em Estados e Municípios. Diário Oficial da União, Brasília, 20 maio, 2004. Seção 1, p. 52.

6. Medronho RA, Carvalho DM, Bloch KV, Ronir RL, Werneck GL. Epidemiologia. 2ª ed. São Paulo: Atheneu; 2004.

7. Stata Corp. Data Analysis and Statistical Software. Release 11. College Station, TX: StataCorp LP; 2009.
8. Lettiere A, Nakano AMS, Rodrigues DT. Violence against women: visibility of the problem according to the health team. Rev Esc Enferm USP [Internet]. 2008 [cited 2013 May 15];42(3):467-73. Available from: http://www.scielo.br/pdf/ reeusp/v42n3/en_v42n3a07.pdf

9. Oliveira CC, Almeida MAS, Morita I. Violência e saúde: concepções de profissionais de uma Unidade Básica de Saúde. Rev Bras Educ Med. 2011;35(3):412-20.

10. Souza ER, Ribeiro AP, Penna LHG, Ferreira AL, Santos NC, Tavares CMM. O tema violência intrafamiliar na concepção dos formadores dos profissionais da saúde. Ciênc Saúde Coletiva. 2009;14(5):1709-19.

11. Teixeira RR. O acolhimento num serviço de saúde entendido como uma rede de conversações. In: Pinheiro RE, Mattos RA, organizadores. Construção da integralidade: cotidiano, saberes e práticas em saúde. Rio de Janeiro: UERJ/IMS/ ABRASCO; 2003. p. 49-61.

12. Camargo Junior KR, Campos EMS, Bustamante-Teixeira MT, Mascarenhas MTM, Mauad NM, Franco TB, et al. Avaliação da atenção básica pela ótica politico-institucional e da organização da atenção com ênfase na integralidade. Cad Saúde Pública. 2008;24 Supl 1:S58-68.

13. Merhy EE, Campos GWS, Cecílio LCO, organizadores. Inventando a mudança na saúde. São Paulo: Hucitec; 1994.

14. Villela WV, Lago T. Conquistas e desafios no atendimento das mulheres que sofreram violência sexual. Cad Saúde Pública. 2007;23(2):471-5. 